\title{
EFL Teacher Preparation Programs in Saudi Arabia: An Evaluation Comparing Status with TESOL Standards
}

\author{
Abdullah Abdul Muhsen AlHarbi \\ Islamic University of Madinah, Saudi Arabia
}

\begin{abstract}
This descriptive study aims to explore the efficiency of English language teacher preparation programs in Saudi Arabia according to TESOL standards. The study uses a 28 item (across five domains) questionnaire to collect data from one hundred and fortyone male and female EFL teachers in Saudi Arabia. Results show that the TESOL standards are included to a fair degree in the current preparation programs for EFL teachers in Saudi Arabia. The TESOL standards range from 75.8\% to 83.5\%, meaning that the failure of the preparation programs for TESOL standards ranged from $16.5 \%$ to $24.2 \%$. The results also indicate statistically significant differences between the programs for preparing EFL teachers, attributable to the universities and colleges from which they graduate. Finally, the study makes some recommendations based on its results to raise English language teachers' preparation programs in Saudi Arabia.
\end{abstract}

Keywords: EFL teachers, Standard of teacher training, Teacher preparation programs, TESOL.

\section{INTRODUCTION}

Education aims to help learners acquire tools of learning while correcting and facilitating situations and circumstances that help them acquire knowledge, information, experience, and practical skills useful to lead their lives. This process starts with school education which is usually the first and foremost exposure of learners to the world beyond.

The education process is based on scientific and technical foundations, and it is also a complex dynamic process. It includes the teacher, the study materials, the associated activities and methods, among other things. Moreover, because the teacher represents the cornerstone of the education process, he/ she must be prepared to hone their teaching skills, learning practices that best suit the needs of the learners and not be satisfied with the inclination and willingness to practice this profession. In line with this, training during the preparation program and professional exercise play a major role in empowering the teachers to teach with high efficiency.

The process of teacher preparation is a fundamental basis of educational development policies and strategies in most countries of the world, where global educational policies, despite their differences, focus on the importance of upgrading the process of preparing and qualifying teachers because upgrading teacher preparation programs increases the effectiveness of the educational system (AlShukri, 2018, p. 76).

The preparation of teachers in various educational institutions is receiving significant attention from policymakers given the massive research in this area and the greater emphasis on identifying and fulfilling learner needs. Consequently, much like teachers in other areas of specialization, English language teachers are not far from the reality of preparation and development that contemporary trends call for (Al-Ahdal, 2014; Shaldan \& Abu Leilah, 2017). The nature of the subject dictates a permanent follow-up and serious effort to develop and adapt for the better. It also dictates their mastery of the elements of the educational process competencies that they acquired as teachers of the English language. Although specialists follow the teacher preparation process, the role so far of continuous development and updation is insufficient. The role of the teacher in this dispensation is no longer limited to imparting knowledge to students; rather, it encompasses the ability to become organized and prepared for the developing conditions and atmosphere of education, to provide opportunities for students to interact freely and effectively with educational materials and activities.

Saudi Arabia has taken many significant measures to develop professional education and training programs for teachers, including setting professional standards for teachers through the National Authority for Education Evaluation, in line with the Kingdom's 2030 vision. This study comes as part of development attempts to explore the opinions of English language teachers about their current preparation programs in the Kingdom of Saudi Arabia to judge them according to international standards, which are the standards of the

Corresponding Author e-mail: binrobeiq@gmail.com https://orcid.org/0000-0002-7889-3895

How to cite this article: Al-Harbi AAM (2021). EFL Teacher Preparation Programs in Saudi Arabia: An Evaluation Comparing Status with TESOL Standards. Pegem Journal of Education and Instruction, Vol. 11, No. 4, 2021, 237-248

Source of support: Nil

Conflict of interest: None.

DOI: $10.47750 /$ pegegog.11.04.23

Received: 17.06.2021

Accepted: 26.08.2021 Publication: 01.10.2021 
International Organization for Teaching English to Speakers of Other Languages (TESOL).

\section{Research Problem}

The researcher has had the opportunity to prepare teachers in educational universities and colleges, a foray which enabled him to observe the weaknesses in the English language teacher preparation programs in Saudi Arabia, prompting him to conduct this study, especially the role of the current English language teacher preparation programs considering TESOL standards, and the study problem was identified in the following question:

- Considering the TESOL standards, how much do the EFL teachers gain from the current preparation programs in Saudi Arabia in terms of the ability to teach English as a foreign language in a social and cultural context, including the crucial step of assessment and evaluation?

- What is the level of English language teachers' ability to apply planning and implementation instructions impacting their professional and leadership roles due to the current preparation programs in the Kingdom of Saudi Arabia?

- Are there statistically significant differences between teachers due to gender, experience, or the university where the preparation program was completed?

\section{Objectives of the Study}

The study sought to achieve the following objectives:

- Determining the level of language knowledge of English EFL teachers gained from the current EFL teachers' preparation programs in Saudi Arabia considering TESOL standards.

- Recognizing the level of English language teachers' ability to teach English as a foreign language in a social and cultural context through what they have learned in current preparation programs in Saudi Arabia considering TESOL standards.

- Identifying the level of English language teachers' ability to apply planning and implementation instructions through what they have learned in current preparation programs in Saudi Arabia considering TESOL standards.

- Specifying the level of English language teachers' ability to apply measurement and evaluation procedures through what they have learned about the current preparation programs in Saudi Arabia considering TESOL standards.

- The degree of professionalism and leadership that the English language teachers gained through what they have learned from current preparation programs in Saudi Arabia considering TESOL standards.

- Determining the statistically significant differences between EFL teachers due to gender, experience, or the university where the preparation program was completed.

\section{The Importance of the Study}

The study provides a comprehensive and clear evaluation of English language teacher preparation progrmas in Saudi Arabia universities in the light of TESOL standards. It is expected that this study will benefit the faculties of education in the universities in preparing teachers in general, and in preparing English language teachers, especially in the Saudi universities and taking into account its results and recommendations for improving the reality of preparing teachers, developing study plans for departments, and facing some existing challenges.

\section{The Limits of the Study}

The study is limited to knowing the EFL teachers' perceptions about the level of EFL teachers' preparation programs in Saudi universities according to TESOL Standards in the academic year 2020/2021.

\section{Literature Review}

\section{EFL Teachers' Preparation Programs in Saudi Arabia}

The study of Alrwele (2018) aimed to identify the level of teaching competencies for female field training students in the Department of English, in the light of the professional standards for English language teachers, set by the National Center for Assessment and Evaluation in Higher Education in the Kingdom of Saudi Arabia. The results of the study showed that the trainees believed that they had a high degree of competence in the language proficiency standards (68.4) and theoretical knowledge (27.4), but that they were not sure of their competence in the application of theories (37.3), the core of the curriculum (14.3), and the science of language teaching (18.2).

A study conducted by Al-Abiky (2019) aimed to examine the reasons for the low English achievements of students in Saudi Arabia. It clarified that although English was a core school subject in Saudi Arabia, and the language itself has been around in the country for almost a century, the EFL teachers' preparation programs in Saudi Arabia still fail to deliver, help, or even set a plan for change as the English proficiency for Saudi students in schools and colleges. The study recommended that more serious redemptive measures were needed in addition to the recent efforts.

The study of AL-Muzeini and Al-Kahtani (2020) aimed to evaluate the English language teacher preparation and training programs and present a vision for their development. Based on its results, the study recommended that the period of field training should be increased in these programs. This study also recommended that the English language teacher preparation programs be continuously reviewed and changed to match the requirements of the rapid global developments.

The study of Youssef (2020) aimed to find how to prepare the teachers in the light of the challenges of the twenty-first 
century? The study identified the importance of preparing teachers in various disciplines, whether before or during service. Because the teacher's job changes with the change of contemporaneous life and its requirements, it is important to consider these variables to build a new generation, as the criteria for judging the level of education in any country is the level of teacher preparation and training programs, and this requires comprehensive preparation, especially with the vast growth in the volume of scientific and human knowledge.

The study of Alshuaifan (2021) aimed to characterize and compare the role of the EFL/ESL teacher preparation programs in raising the awareness of pre-service teachers of the ICC Model in Saudi Arabia and Singapore. The results showed the availability of the ICC (Intercultural Communicative Competence) in the EFL/ESL teacher preparation program in both countries. The study recommended reviewing and continually updating the EFL/ESL teacher preparation program at the College of Education according to the ICC Model to meet students' needs and ensure their communicative competence.

In conclusion, the above studies indicated that Saudi EFL teachers need to enforce their skills to know apply educational theories, be trained in curriculum design and teaching methods. Further, that the EFL teachers' preparation programs in Saudi Arabia still fail to deliver, help, or even set a plan for change as the English proficiency for Saudi students in schools and colleges continues to be low.

\section{EFL Teachers' Preparation Programs in other Arab Countries}

A study by AlJebol (2014) aimed to identify the English teachers' perception level in different educational stages for their professional development in public schools. The results showed that The English teachers' perception level in different educational stages for their professional development was moderate in all domains. It also indicated that significant differences prevailed in English teachers' perception level for their professional development due to their gender in favor of the male teachers on the technological domain and in favor of the female in the professional activities domain.

Another study by Youcef and Taoufik (2015) aimed to examine the adequacy of the pre-service training program at the Department of English at Tlemcen University, Algeria. The findings of this multi-method study conducted at the Department of English with a sample of 108 students showed that first- and second-language acquisition processes, assessment procedures, educational psychology, and lack of teaching practice are among the major problems that should be addressed to render the current pre-service teacher training program to prepare professionally qualified EFL teachers.

Shaldan and Abu Leilah (2017) aimed to explore the standards of the English language teacher preparation programs in Palestinian universities in the Gaza governorates in the light of the NCATE-Education Teacher National Council for Accreditation of NCATE standards. The results showed that the English language teacher preparation programs in the Palestinian universities in the Gaza governorates in the light of the NCATE criteria reached a relative weight of $(42.68 \%)$ with a high degree of appreciation. It also indicated statistically significant differences due to the "university" study variable in all fields, and in favor of Al-Quds Open University, except for the fifth domain, "faculty members," which was in favor of Al-Azhar university. The study suggested updating English language teacher preparation programs by incorporating recent research findings. It also suggested paying attention to the professional development of the English language teaching staff members through training courses.

The study of Manaserah and Al-Halali (2017) aimed to identify the degree of contribution of English language teacher prep programs in achieving social development goals from the viewpoint of English language teachers and supervisors. The most significant result was that the English language teacher preparation programs contribute to a moderate degree in achieving social development goals from the viewpoint of English language supervisors and teachers. The study's most prominent recommendation indicated the importance of reviewing the plans of the EFL teachers' preparation programs in light of the demands and objectives of social development.

A study by Alja'afreh (2020) aimed to determine the effectiveness of the New Teachers Program in developing the teaching competencies of English language teachers in the Karak Kasbah education directorate in Jordan. The results indicated that the overall effectiveness of the new teacher's program in developing teaching competencies at the whole tool level, which was high at a mean score of 3.75 out of a maximum of 5. It suggested that the New Teachers' Program was suitable to develop the teaching competencies of the English teachers in Jordan and other Arab countries.

Abu Jeriban (2020) aimed to identify the professional needs of new Jordanian English language teachers as perceived by them. The results showed that the English language teachers' needs for professional development were high. It also showed a great need for preparation in teaching methods and the integration of modern technologies into the teaching process.

In conclusion, the studies showed that the teacher training programs needed revamping, recognizing that there is a great need for rethinking in teaching methods and the integration of modern technologies into the teaching process.

\section{EFL Teachers' Preparation Programs outside Arabian Countries}

The study of Goff et al. (2020) introduced a new approach to measuring the effectiveness of teacher preparation programs at US universities (TPP) by examining to what extent TPPs 
produced employable teacher candidates. The study used teacher application data in Wisconsin public schools from 2014-15 through 2016-17. It found that attending a specific university's TPP differed for novice teacher applicants' job outcomes. However, the competitiveness of a TPP is inextricable from the geographic locale in which it operated. These findings called into question the validity of acontextual and absolute TPP rankings. Study results suggested that graduates of TPPs with strong school and community partnerships were more competitive in the local labor market.

The purpose of the study of Meihami (2021) was to identify the role of PEPAs (Potentially Exploitable Pedagogical Activities) in EFL teachers' professional identity development. The findings of the study showed that the development across the five indicators (self-efficacy, professional commitment, task orientation, work motivation, and future perspective) after the two EFL teachers participated in the PEPA program, indicating that PEPAs had a positive and constructive role in developing EFL teachers' professional identity. It can be concluded that PEPAs help the teachers develop their syllabuses based on practice-as-research.

The goal of the study conducted by Ürün Göker (2021) was to inquire into the impact of reflective coaching (RC) on the development of pre-service EFL (English as a Foreign Language) teachers' sense of efficacy and instructional skills. Its results showed significant differences in favor of implementing the RC program on the development of preservice EFL (English as a Foreign Language) teachers' sense of efficacy and instructional skills.

In conclusion, the non-Arabic studies discussed the effectiveness of some new approaches and methods in EFL teachers' preparation programs, like the role of PEPAs, RC, and TPPs. Further, all previous studies agreed that there is a need to develop the preparation of EFL teachers, although some of them studied the reality of the current preparation programs and the weaknesses in them and the areas that needed improvement, especially on the count of teaching methods and the integration of modern technologies. Some other studies tried the effectiveness of some ready-made models in preparation and some new trends and methods in preparing English language teachers. Generally, there is a trend discernible in most studies on the need for improvement and development and suggestions for experimenting with new methods and models to teach students the English language as desired.

\section{Method}

As stated earlier, this study takes a descriptive approach, through which he tried to describe the subject of the study, the analysis of its data, the relationship between its components, and the opinions presented about it. It follows the survey method by using an instrument for data collection which is a questionnaire based on an earlier TESOL model, which is administered to 141 male and female trained teachers in Saudi Arabia.

\section{Instrumentation}

The questionnaire used in the current study was developed according to standards for initial TESOL pre-K-12 teacher preparation programs designed by TESOL (2019) after some edits for some of its items. The edited questionnaire consists of 5 sub-dimensions which are: language knowledge, ELLS in the sociocultural context, planning and implementing instruction, professionalism and leadership, and assessment and evaluation. The responses are sought in a 5-point Likert Scale in which the scope of the answers varies from strongly disagree (1), disagree (2), neutral (3), agree: (4), and strongly agree (5). The questionnaire consisted of 28 items, and its interitem reliability was measured by ALPHA Cronbach at (0.96), which made this tool trustworthy and its results generalizable.

\section{The Population and Sampling}

The study population comprises all English language teachers who have graduated from preparation programs offered in

Table 1: The sample of the study

\begin{tabular}{|c|c|c|c|c|c|}
\hline \multirow{2}{*}{$\begin{array}{l}\text { University } \\
\text { Male }\end{array}$} & & \multicolumn{3}{|l|}{$\operatorname{Sex}$} & \multirow[b]{2}{*}{ Total } \\
\hline & & Female & Percentage & & \\
\hline & Taibah University & $16.4 \%$ & 10 & $13.5 \%$ & 21 \\
\hline & King Abdul Aziz University & $16.4 \%$ & 14 & $18.9 \%$ & 25 \\
\hline & Teachers Colleges & $20.9 \%$ & 4 & $12.8 \%$ & 18 \\
\hline & King Saud University & $26.9 \%$ & 5 & $6.8 \%$ & 23 \\
\hline & King Faisal University & $7.5 \%$ & 13 & $17.6 \%$ & 18 \\
\hline & Bisha University & $0.0 \%$ & 18 & $24.3 \%$ & 18 \\
\hline & Umm Al-Qura University & $11.9 \%$ & 10 & $13.5 \%$ & 18 \\
\hline \multirow[t]{2}{*}{ Total } & & $47.5 \%$ & 74 & $52.5 \%$ & 141 \\
\hline & & & $100 \%$ & & \\
\hline
\end{tabular}


Saudi universities and teacher colleges in the academic year 2020-2021, currently teaching EFL in public education schools. The number of community members was not specified in this study because its nature confirms that: "Studying the sample is better than studying the entire community because of the speed of obtaining data from the sample, and the low costs" (Abu Allam, 2006, p. 270). The sample of the study consisted of 141 male and female teachers. Table (1) below shows the demographic distribution of the sample.

\section{Data Collection and Statistical Treatment}

To reach the objectives of the study and answer its questions, the researcher used the following statistical methods:

- Cronbach's alpha coefficient to calculate the stability of the study tool.

- Frequencies and percentages.

- T-test to determine the differences in the responses of the study sample according to gender.

- ANOVA test was used to determine the differences in the responses of the study sample according to the academy from which the teacher graduated

Approved Criterion: The tool of the study was measured according to the Likert scale. The relative weight was obtained by calculating the range between the degrees of the scale $(1-5=4)$. Second, it can be calculated by measuring its value by the most significant value in the scale to get the relative weight (percentage) $(80.0=5 / 4)$. Then, this value was added to the lower value in the scale (the beginning of the scale is number one) to determine the upper limit of this range; thus, the length of the ranges became as shown in Table (2) (Melham, 2000, p. 42).

Table 2: The Scale Used in the Study to the Mean and Relative Weight

\begin{tabular}{lll}
\hline Mean & Relative Weight & Extent of Agreement \\
\hline From 1 to 1.80 & 20\% to 36\% & Strongly Disagree \\
More than 1.80 to 2.60 & More than 36\% to 52\% & Disagree \\
More than 2.60 to 3.4 & More than 52\% to 68\% & Undecided (Neutral) \\
More than 3.40 to 4.20 & More than 68\% to 84\% & Agree \\
More than 4.20 to 5 & More than 84\% to 100\% & Strongly Agree \\
\hline
\end{tabular}

\section{Results and Discussion}

This part of the research included a presentation of the study results by answering the study's questions and the most prominent results of the questionnaire reached through the analysis of its items. The study's main question: What is the level of EFL teacher's preparation programs in Saudi Arabia considering TESOL standards?

To answer the central question, the researcher calculated the mean of the teachers' responses and put their relative weight as shown in the following table.

Table 3 shows that the total score of the English language teacher preparation programs in the Saudi universities and colleges in the light of TESOL standards from the point of view of the English language teaching staff was highly appreciated $(\mathrm{M}=4.06, \mathrm{SD}=.72587)$, with relative weight $(81.3 \%)$. The researcher attributes this to:

- Most Saudi universities are striving to apply international standards that improve their programs and develop their performance.

- There is a need to activate standards in all academic programs in universities, colleges, and institutes to improve the quality of the human product.

The obtained result did not differ much from the result of Shaldan and Abu Leilah (2017), in which the level of the EFL preparation programs was $68.42 \%$, whereas the level in the current study looked better to some extent, at $81.3 \%$. It differed from the result of AlShukri (2018) in which the level of the EFL preparation programs was $63.6 \%$, indicating a moderate level.

The study then moves on to check the level of language knowledge of English EFL teachers as gained from the current preparation programs in the Kingdom of Saudi Arabia.

For this, the researcher used the arithmetic mean and standard deviation, as shown in Table (4).

Table 4 shows that the level of language knowledge gained by Saudi EFL teachers as a result of the prep programs was high because the total responses for the teachers were $(M=4.17$ $(83.5 \%), \mathrm{SD}=.84970)$. This result means that the EFL teachers' current preparation programs can provide them with the needed language knowledge to teach English language for K-12 students in Saudi schools. The obtained result was different from the result of a study by Shaldan and Abu Leilah (2017) in

Table 3: The level of teacher preparation programs according to TESOL standards.

\begin{tabular}{|c|c|c|c|c|c|}
\hline Domains & $N$ & Mean & Relative weight & Std. Deviation & Order \\
\hline Language Knowledge & 141 & 4.1759 & $83.5 \%$ & .84970 & 1 \\
\hline ELLS in the sociocultural context & 141 & 3.7943 & $75.8 \%$ & .80070 & 5 \\
\hline Planning and implementing instruction & 141 & 4.1324 & $82.6 \%$ & .77754 & 2 \\
\hline Professionalism and leadership & 141 & 4.1092 & $82.2 \%$ & .82893 & 4 \\
\hline Assessment and evaluation & 141 & 4.1277 & $82.5 \%$ & .82655 & 3 \\
\hline Total & 141 & 4.0679 & $81.3 \%$ & .72587 & \\
\hline
\end{tabular}


which the level of teachers in this dimension was low at 56.17 $\%$. As shown in Table (4), the results of teachers' responses to the statements of this dimension were generally close and the researcher hardly found differences between them. The result appeared through the scores and their relative weight, where all the statements ranged from $81.4 \%$ to $85.6 \%$.

On the question of the English language teachers' ability to teach English as a second language in a social and cultural context through what they have learned in current preparation programs in Saudi Arabia, the researcher calculated the mean of the teachers' responses to it and put their relative weight as shown in the following Table 5.

Table 5 shows that the results in this dimension were poorer than the previous one, but they are still in the high range $(\mathrm{M}=$ $3.79(75.8 \%), \mathrm{SD}=.80070)$. This domain was not included in any of the previous studies; therefore, it cannot be compared with other results.
As far as the level of English language teachers' ability to apply planning and implementation instructions through what they have learned in current preparation programs in the Kingdom of Saudi Arabia goes, the researcher calculated the mean of the teachers' responses to it and put their relative weight as shown in the following table 6.

Table (6 shows that the level of EFL teachers' programs in this dimension was high $(\mathrm{M}=4.13, \mathrm{SD}=.77754)$, with relative weight at $82.6 \%$. The obtained result differed from that of Shaldan and Abu Leilah (2017) which was low at 51.4\%.

To find out whether professionalism and leadership qualities were gained by the English language teachers through what they have learned from current preparation programs in Saudi Arabia, the researcher calculated the mean of the teachers' responses to it, the frequency, the relative weight of the responses to the items related to professionalism and leadership as shown in the following table 7.

Table 4: Descriptive statistics related to Language Knowledge

\begin{tabular}{|c|c|c|c|c|}
\hline Item & $N$ & Mean & Relative Weight & $S D$ \\
\hline $\begin{array}{l}\text { I can prove knowledge of English language structures in different discourse contexts } \\
\text { to promote reading, writing, speaking, and listening skills across content areas. }\end{array}$ & 141 & 4.2270 & $84.5 \%$ & .95146 \\
\hline I serve as language models for ELLs. & 141 & 4.2837 & $85.6 \%$ & .92061 \\
\hline $\begin{array}{l}\text { I can prove knowledge of second language acquisition theory and the developmental } \\
\text { process of language to set expectancies for and facilitate language learning. }\end{array}$ & 141 & 4.0851 & $81.7 \%$ & .91409 \\
\hline $\begin{array}{l}\text { I can prove language processes (e.g., interlanguage and language progressions) to } \\
\text { facilitate and monitor ELLs' language learning in English. }\end{array}$ & 141 & 4.2128 & $84.2 \%$ & 1.02684 \\
\hline $\begin{array}{l}\text { I can apply knowledge of English academic language functions, learning domains, } \\
\text { content-specific language, discourse structures, and vocabulary to promote ELLs' } \\
\text { academic achievement across content areas. }\end{array}$ & 141 & 4.0709 & $81.4 \%$ & 1.01168 \\
\hline Total & 141 & 4.1759 & $83.5 \%$ & .84970 \\
\hline
\end{tabular}

Table 5: Descriptive statistics related to ELLS in the sociocultural context

\begin{tabular}{|c|c|c|c|c|}
\hline Items & $\mathrm{N}$ & Mean & Relative weight & $\mathrm{SD}$ \\
\hline $\begin{array}{l}\text { I can prove how dynamic academic, personal, familial, cultural, and social contexts, } \\
\text { including sociopolitical factors, impact the education of ELLs. }\end{array}$ & 141 & 4.1702 & $83.4 \%$ & .94080 \\
\hline $\begin{array}{l}\text { I can prove knowledge of research and theories of cultural and linguistic diversity and } \\
\text { equity that promote academic and social language learning for ELLs. }\end{array}$ & 141 & 3.6596 & $73.2 \%$ & 1.12650 \\
\hline $\begin{array}{l}\text { I can devise and implement methods to understand each ELL's academic characteristics, } \\
\text { including background knowledge, educational history, and current performance data, } \\
\text { to develop effective, individualized instructional and assessment practices for their }\end{array}$ & 141 & 3.8085 & $76.2 \%$ & 1.05502 \\
\hline $\begin{array}{l}\text { I can devise and implement methods to learn about the personal characteristics of } \\
\text { the individual ELL (e.g., interests, motivations, strengths, needs) to develop effective } \\
\text { instructional practices. }\end{array}$ & 141 & 3.9504 & $79 \%$ & 1.06453 \\
\hline $\begin{array}{l}\text { I can devise and implement methods to learn about characteristics of the ELL's family } \\
\text { (e.g., language use, literacy practices, circumstances) to develop effective instructional } \\
\text { practices. }\end{array}$ & 141 & 3.5390 & $70.8 \%$ & 1.08574 \\
\hline $\begin{array}{l}\text { I can identify and describe the effect of his/her identity, role, cultural understandings, } \\
\text { personal biases, and conscious knowledge of US culture on his/her interpretation of } \\
\text { the educational strengths and needs of individual ELLs and ELLs in general. }\end{array}$ & 141 & 3.6383 & $72.8 \%$ & 1.05069 \\
\hline Total & 141 & 3.7943 & $75.8 \%$ & .80070 \\
\hline
\end{tabular}


Table (7) clearly shows that the current Saudi EFL teachers' programs covered the dimension of professionalism and leadership to a high level at $82.2 \%(\mathrm{M}=4.10, \mathrm{SD}=.82893)$. This result differed from that of Shaldan and Abu Leilah (2017) study, in which the level was moderate at $62.9 \%$. The result also is better than that of Alja'afreh (2020) which reflected a high percentage at in $75 \%$.

Concerning the level of English language teachers' ability to apply assessment and evaluation procedures through what they have learned about the current preparation programs in the Kingdom of Saudi Arabia, the frequency, relative weight, and percentage of the responses to the items related to assessment and evaluation were calculated, summarized in table 8 .

Table (8) shows that Saudi EFL teachers' preparation programs presented the dimension of assessment and evaluation with high level at $82.5 \%,(\mathrm{M}=4.12, \mathrm{SD}=.82655)$. This result means that the rate of failure of EFL teacher preparation programs to reach the level of TESOL standards is $14.5 \%$, which is not a lot and can be improved through programs' future development processes. This result also is better than that of Shaldan and Abu Leilah (2017) which was moderate at $62.5 \%$ in this domain.

The study then identifies if there are statistically significant differences between teachers' responses due to gender or the university at which the preparation program was completed. A T-test was used to explore differences between the teachers' responses according to their gender (male/female), results shown in table 9.

Table (9) shows that no statistical differences exist between the responses of EFL teachers due to their gender. This result is consistent with the results of Shaldan and Abu Leilah (2017) and AlJebol (2014). However, it differed from that of AlShukri (2018), which indicated that there are statistical differences between male and female teachers. This result may be attributed to the fact that the exact content of EFL teachers' preparation programs is offered to males and females.

An ANOVA test was used to explore differences between the teachers' responses according to their universities and colleges, as shown in table (10). The research also used

Table 6: Descriptive statistics related to planning and implementing instruction

\begin{tabular}{|c|c|c|c|c|}
\hline & $N$ & Mean & Relative weight & $S D$ \\
\hline $\begin{array}{l}\text { I can plan for culturally and linguistically relevant, supportive environments that } \\
\text { reinforce ELLs' learning. }\end{array}$ & 141 & 3.9929 & $79.8 \%$ & 1.01063 \\
\hline $\begin{array}{l}\text { I can design scaffolded instruction of language and literacies to support standards } \\
\text { and curricular objectives for ELLs' in the content areas }\end{array}$ & 141 & 4.1064 & $82 \%$ & .85942 \\
\hline $\begin{array}{l}\text { I can instruct ELLs using evidence-based, student-centered, developmentally } \\
\text { adequate interactive approaches. }\end{array}$ & 141 & 4.3262 & $86.5 \%$ & .88234 \\
\hline $\begin{array}{l}\text { I can adjust instructional decisions after critical reflection on ELLs' learning outcomes } \\
\text { in both language and content. }\end{array}$ & 141 & 4.0213 & $80 \%$ & 1.01748 \\
\hline $\begin{array}{l}\text { I can plan strategies to collaborate with other educators, school personnel, and } \\
\text { families to support their ELLs' learning of language and literacies in the content areas. }\end{array}$ & 141 & 4.1064 & $82 \%$ & .98345 \\
\hline $\begin{array}{l}\text { I can use and adapt relevant materials and resources, including digital resources, } \\
\text { to plan lessons for ELLs, support communication with other educators, school } \\
\text { personnel, and ELLs, and foster student learning of language and literacies in the } \\
\text { content ar }\end{array}$ & 141 & 4.2411 & $84.8 \%$ & .94037 \\
\hline Total & 141 & 4.1324 & $82.6 \%$ & .77754 \\
\hline
\end{tabular}

Table 7: Descriptive statistics related to professionalism and leadership

\begin{tabular}{|c|c|c|c|c|}
\hline Items & $\mathrm{N}$ & Mean & Relative weight & SD \\
\hline $\begin{array}{l}\text { I can prove effective collaboration strategies to plan ways to serve as a resource for } \\
\text { ELL instruction, support educators and school staff, and bolster for ELLs. }\end{array}$ & 141 & 3.9787 & $79.5 \%$ & .96709 \\
\hline $\begin{array}{l}\text { I apply knowledge of the school, district, and governmental policies and legislation } \\
\text { that impact ELLs' educational rights to bolster for ELLs. }\end{array}$ & 141 & 4.0709 & $81.4 \%$ & .93843 \\
\hline I practice self-assessment and reflection, make adjustments for self-improvement. & 141 & 3.9574 & $79 \%$ & .94772 \\
\hline $\begin{array}{l}\text { I can plan for continuous professional development in the field of English language } \\
\text { learning and teaching. }\end{array}$ & 141 & 4.1915 & $83.8 \%$ & 1.08176 \\
\hline $\begin{array}{l}\text { I engage in supervised teaching to apply and develop their professional practice using } \\
\text { self-reflection and feedback from their cooperating teachers and supervising faculty. }\end{array}$ & 141 & 4.3475 & $86.9 \%$ & .97090 \\
\hline Total & 141 & 4.1092 & $82.2 \%$ & .82893 \\
\hline
\end{tabular}


Table 8: Descriptive statistics related to assessment and evaluation

\begin{tabular}{|c|c|c|c|c|}
\hline items & $\mathrm{N}$ & Mean & $\begin{array}{l}\text { R e l a t i v e } \\
\text { weight }\end{array}$ & $\mathrm{SD}$ \\
\hline $\begin{array}{l}\text { I can apply knowledge of validity, reliability, and assessment purposes to } \\
\text { analyze and interpret student data from multiple sources, including norm- } \\
\text { referenced and criterion-referenced tests. }\end{array}$ & 141 & 4.0851 & $81.7 \%$ & .97460 \\
\hline I can make informed instructional decisions that support language learning. & 141 & 4.2837 & $85.6 \%$ & 90496 \\
\hline $\begin{array}{l}\text { I can prove an understanding of classroom-based formative, summative, and } \\
\text { diagnostic assessments scaffolded for both English language and content } \\
\text { assessment. }\end{array}$ & 141 & 4.2695 & $85.4 \%$ & .85255 \\
\hline $\begin{array}{l}\text { I can determine language and content learning goals based on assessment } \\
\text { data. }\end{array}$ & 141 & 4.2908 & $85.8 \%$ & .90663 \\
\hline $\begin{array}{l}\text { I can prove state-approved administrative considerations, accessibility } \\
\text { features, and accommodations adequate to ELLs for standardized assessments. }\end{array}$ & 141 & 4.0567 & $81 \%$ & 1.00551 \\
\hline $\begin{array}{l}\text { I can prove how English language proficiency assessment results are used for } \\
\text { identification, placement, and reclassification. }\end{array}$ & 141 & 3.7801 & $75.6 \%$ & 1.16553 \\
\hline Total & 141 & 4.1277 & $82.5 \%$ & .82655 \\
\hline
\end{tabular}

Table 9: T-test statistics of differences according to gender

\begin{tabular}{|c|c|c|c|c|c|c|}
\hline Domains & $\operatorname{sex}$ & $\mathrm{N}$ & Mean & SD & $\mathrm{F}$ & Sig. \\
\hline \multirow[t]{2}{*}{ Language knowledge } & Male & 67 & 3.9194 & .84499 & \multirow[t]{2}{*}{1.007} & \multirow[t]{2}{*}{.317} \\
\hline & Female & 74 & 4.4081 & .78996 & & \\
\hline \multirow[t]{2}{*}{ ELLS sociocultural context } & Male & 67 & 3.5100 & .72873 & \multirow[t]{2}{*}{.252} & \multirow[t]{2}{*}{.617} \\
\hline & Female & 74 & 4.0518 & .77975 & & \\
\hline \multirow{2}{*}{$\begin{array}{l}\text { Planning and implementing } \\
\text { instruction }\end{array}$} & Male & 67 & 3.9602 & .72654 & \multirow[t]{2}{*}{.222} & \multirow[t]{2}{*}{.638} \\
\hline & Female & 74 & 4.2883 & .79395 & & \\
\hline \multirow[t]{2}{*}{ professionalism and leadership } & Male & 67 & 3.7821 & .78217 & \multirow[t]{2}{*}{.839} & \multirow[t]{2}{*}{.361} \\
\hline & Female & 74 & 4.4054 & .75994 & & \\
\hline \multirow[t]{2}{*}{ Assessment and evaluation } & Male & 67 & 3.8458 & .76283 & \multirow[t]{2}{*}{.131} & \multirow[t]{2}{*}{.718} \\
\hline & Female & 74 & 4.3829 & .80321 & & \\
\hline \multirow[t]{2}{*}{ Total } & Male & 67 & 3.8035 & .61914 & \multirow[t]{2}{*}{1.230} & \multirow[t]{2}{*}{.269} \\
\hline & Female & 74 & 4.3073 & .73595 & & \\
\hline
\end{tabular}

descriptive statistics to determine statistical differences between universities/colleges, which is trending in favor of any of them, as shown in table (11).

Tables (10) and (11) show the prevalence of statistical differences between EFL teachers' perceptions, in general, towards their preparation programs according to the universities or colleges they graduated from them. There were statistical differences between EFL teachers' perceptions in the domain of language knowledge (Sig.= .012). These differences favored Bisha University $(\mathrm{M}=4.53, \mathrm{SD}=.42288)$ and King Saud University $(\mathrm{M}=4.4, \mathrm{SD}=.56847)$. As we have seen, the results of the two universities are close in this dimension. Perhaps this is because the University of Bisha was originally a branch of King Saud University before it became independent under its current name. The lowest two universities in this dimension were Taibah University $(\mathrm{M}=3.86, \mathrm{SD}=1.06646)$, and King Abdul Aziz University $(M=3.75, S D=.97002)$. Their results were also close because Taibah university was originally a King Abdul Aziz University branch in Madinah city. In general, the TESOL standards for language knowledge were available in EFL teacher preparation programs in Saudi Arabia, with rates ranging from $75 \%$ to $90.6 \%$

Tables (10) and (11) also show that the TESOL standards for ELLS sociocultural context dimension were available in EFL teacher preparation programs in Saudi Arabia, with rates ranging from $67.6 \%$ to $87.4 \%$. There were statistical differences between EFL teachers' perceptions in the domain of ELLS sociocultural context (Sig.=.002). These differences favored Bisha University $(\mathrm{M}=4.37, \mathrm{SD}=.80755)$ and Um Al-Qura University $(\mathrm{M}=4.25, \mathrm{SD}=.42179)$. The lowest two universities in this dimension were King Abdul Aziz University $(\mathrm{M}=3.38$, $\mathrm{SD}=.89949)$, and King Saud University $(\mathrm{M}=3.63, \mathrm{SD}=.59809)$.

In planning and implementing instructions, the TESOL standards were available in EFL teacher preparation programs 
Table (10): ANOVA according to EFL teachers' universities/colleges

\begin{tabular}{|c|c|c|c|c|c|c|}
\hline Domains & & Sum of Squares & $d f$ & Mean Square & $F$ & Sig. \\
\hline \multirow[t]{3}{*}{ Language knowledge } & Between Groups & 11.502 & 6 & 1.917 & 2.868 & .012 \\
\hline & Within Groups & 89.576 & 134 & .668 & & \\
\hline & Total & 101.078 & 140 & & & \\
\hline \multirow{3}{*}{$\begin{array}{l}\text { ELLS sociocultural } \\
\text { context }\end{array}$} & Between Groups & 13.044 & 6 & 2.174 & 3.797 & .002 \\
\hline & Within Groups & 76.714 & 134 & .572 & & \\
\hline & Total & 89.758 & 140 & & & \\
\hline \multirow{3}{*}{$\begin{array}{l}\text { Planning and } \\
\text { implementing } \\
\text { instruction }\end{array}$} & Between Groups & 16.366 & 6 & 2.728 & 5.353 & .000 \\
\hline & Within Groups & 68.274 & 134 & .510 & & \\
\hline & Total & 84.640 & 140 & & & \\
\hline \multirow{3}{*}{$\begin{array}{l}\text { professionalism and } \\
\text { leadership }\end{array}$} & Between Groups & 19.812 & 6 & 3.302 & 5.793 & .000 \\
\hline & Within Groups & 76.386 & 134 & .570 & & \\
\hline & Total & 96.198 & 140 & & & \\
\hline \multirow{3}{*}{$\begin{array}{l}\text { Assessment and } \\
\text { evaluation }\end{array}$} & Between Groups & 24.404 & 6 & 4.067 & 7.650 & .000 \\
\hline & Within Groups & 71.243 & 134 & .532 & & \\
\hline & Total & 95.647 & 140 & & & \\
\hline
\end{tabular}

Table (11): Descriptive statistics related to differences according to EFL teachers' universities/colleges

\begin{tabular}{|c|c|c|c|c|c|}
\hline Domains & & $N$ & Mean & $S D$ & Order \\
\hline \multirow[t]{8}{*}{ Language knowledge } & Taibah University & 21 & 3.8667 & 1.06646 & 5 \\
\hline & $\begin{array}{l}\text { King Abdul Aziz } \\
\text { University }\end{array}$ & 25 & 3.7520 & .97002 & 6 \\
\hline & Teachers Colleges & 18 & 4.2000 & .61739 & 4 \\
\hline & King Saud University & 23 & 4.4957 & .56847 & 2 \\
\hline & King Faisal University & 18 & 4.2000 & 1.17022 & 4 \\
\hline & Bisha University & 18 & 4.5333 & .42288 & 1 \\
\hline & $\begin{array}{l}\text { Umm Al-Qura } \\
\text { University }\end{array}$ & 18 & 4.3111 & .50514 & 3 \\
\hline & Total & 141 & 4.1759 & .84970 & \\
\hline \multirow{8}{*}{$\begin{array}{l}\text { ELLS sociocultural } \\
\text { context }\end{array}$} & Taibah University & 21 & 3.6429 & .70963 & 6 \\
\hline & $\begin{array}{l}\text { King Abdul Aziz } \\
\text { University }\end{array}$ & 25 & 3.3800 & .89949 & 7 \\
\hline & Teachers Colleges & 18 & 3.8796 & .83000 & 3 \\
\hline & King Saud University & 23 & 3.6377 & .59809 & 5 \\
\hline & King Faisal University & 18 & 3.7870 & .98154 & 4 \\
\hline & Bisha University & 18 & 4.3704 & .80755 & 1 \\
\hline & $\begin{array}{l}\text { Umm Al-Qura } \\
\text { University }\end{array}$ & 18 & 4.0926 & .10262 & 2 \\
\hline & Total & 141 & 3.7943 & .80070 & \\
\hline \multirow{8}{*}{$\begin{array}{l}\text { Planning and } \\
\text { implementing } \\
\text { instructions }\end{array}$} & Taibah University & 21 & 3.7460 & .96266 & 6 \\
\hline & $\begin{array}{l}\text { King Abdul Aziz } \\
\text { University }\end{array}$ & 25 & 3.6400 & .94487 & 7 \\
\hline & Teachers Colleges & 18 & 4.1019 & .71661 & 5 \\
\hline & King Saud University & 23 & 4.2101 & .63209 & 3 \\
\hline & King Faisal University & 18 & 4.5648 & .56342 & 1 \\
\hline & Bisha University & 18 & 4.4815 & .50127 & 2 \\
\hline & $\begin{array}{l}\text { Umm Al-Qura } \\
\text { University }\end{array}$ & 18 & 4.4167 & .25725 & 4 \\
\hline & Total & 141 & 4.1324 & .77754 & \\
\hline
\end{tabular}




\begin{tabular}{|c|c|c|c|c|c|}
\hline Domains & & $N$ & Mean & $S D$ & Order \\
\hline \multirow{8}{*}{$\begin{array}{l}\text { Professionalism and } \\
\text { leadership }\end{array}$} & Taibah University & 21 & 3.6381 & .92438 & 6 \\
\hline & $\begin{array}{l}\text { King Abdul Aziz } \\
\text { University }\end{array}$ & 25 & 3.6960 & 1.02976 & 5 \\
\hline & Teachers Colleges & 18 & 4.4000 & .68599 & 3 \\
\hline & King Saud University & 23 & 4.0000 & .62085 & 4 \\
\hline & King Faisal University & 18 & 4.2556 & .82264 & 2 \\
\hline & Bisha University & 18 & 4.7889 & .40857 & 1 \\
\hline & $\begin{array}{l}\text { Umm Al-Qura } \\
\text { University }\end{array}$ & 18 & 4.2556 & .42179 & 2 \\
\hline & Total & 141 & 4.1092 & .82893 & \\
\hline \multirow{8}{*}{$\begin{array}{l}\text { Assessment and } \\
\text { evaluation }\end{array}$} & Taibah University & 21 & 3.7063 & 1.04204 & 7 \\
\hline & $\begin{array}{l}\text { King Abdul Aziz } \\
\text { University }\end{array}$ & 25 & 3.7067 & .95292 & 6 \\
\hline & Teachers Colleges & 18 & 4.3796 & .62047 & 3 \\
\hline & King Saud University & 23 & 3.7391 & .60891 & 5 \\
\hline & King Faisal University & 18 & 4.3704 & .73109 & 4 \\
\hline & Bisha University & 18 & 4.7222 & .40825 & 1 \\
\hline & $\begin{array}{l}\text { Umm Al-Qura } \\
\text { University }\end{array}$ & 18 & 4.6111 & .25565 & 2 \\
\hline & Total & 141 & 4.1277 & .82655 & \\
\hline
\end{tabular}

in Saudi Arabia, with rates ranging from $72.8 \%$ to $91.2 \%$. There were also statistically differences between the perceptions of EFL teachers in the domain of planning and implementing instructions (Sig.= .000). These differences favored King Faisal University $(\mathrm{M}=4.56, \mathrm{SD}=.56342)$ and Bisha University $(\mathrm{M}=$ $4.48, \mathrm{SD}=. .50127)$. The least two universities in this dimension were King Abdul Aziz University $(\mathrm{M}=3.64, \mathrm{SD}=.94487)$, and Taibah University $(\mathrm{M}=3.74, \mathrm{SD}=.96266)$.

The TESOL standards were available in EFL teacher preparation programs in Saudi Arabia, with rates ranging from $72.7 \%$ to $95.8 \%$ in the domain of professionalism and leadership. There were also statistical differences between EFL teachers' perceptions in the domain of professionalism and leadership (Sig.= .000). These differences were in favor of Bisha University $(\mathrm{M}=4.78, \mathrm{SD}=.40857)$, Um Al-Qura University $(\mathrm{M}=4.25, \mathrm{SD}=.42179)$, and King Faisal University $(\mathrm{M}=4.25$, $\mathrm{SD}=.82264)$. The lowest two universities in this dimension were Taibah University $(\mathrm{M}=3.63, \mathrm{SD}=.92438)$, and King Abdul Aziz University $(\mathrm{M}=3.69, \mathrm{SD}=1.02976)$.

As shown in tables (10) and (11), the TESOL standards of assessment and evaluation were also available in EFL teacher preparation programs in Saudi Arabia, with rates ranging from $74 \%$ to $94 \%$. There were also statistically differences between EFL teachers' perceptions in the domain of assessment and evaluation (Sig.=.000). These differences were in favor of Bisha University $(\mathrm{M}=4.72, \mathrm{SD}=.40825)$, Um Al-Qura University $(\mathrm{M}=4.61, \mathrm{SD}=.25565)$. The least two universities in this dimension were King Abdul Aziz University $(\mathrm{M}=3.70$, SD $=.95292)$, and Taibah University $(\mathrm{M}=3.70, \mathrm{SD}=1.04204)$.

\section{Conclusion}

According to the results, all items related to TESOL standards implied in the programs of EFL teacher preparation in Saudi Arabia were rated high. The percentage of TESOL standards in them ranged from $75.8 \%$ (for the domain of ELLS in the sociocultural context) to $83.5 \%$ (for the domain of language knowledge). This result means that there are shortcomings in the current teacher preparation programs ranging from $24.2 \%$ to $16.5 \%$ that universities and colleges must address to obtain better results.

The results also showed no statistical differences between the responses of EFL teachers due to their gender about the EFL teachers' preparation programs considering TESOL standards (Sig. = .269).

The results also showed that there are statistical differences between the responses of EFL teachers due to the universities and colleges they graduated from, about the EFL teachers' preparation programs considering TESOL standards (Sig. = .000) as shown in table (12).

To conclude, the teacher training programs are plotted in the following graph in figure 1 to provide a bird's eye view of the current standards as per TESOL aspirations.

As figure (1) indicates, the University of Bisha obtained the highest percentage in the compatibility of its teacher preparation program with TESOL standards (91.4). It was followed by Umm Al-Qura University (86.6\%) and then King Faisal University (84.6\%). King Abdul Aziz University obtained the lowest percentage of compatibility for the teacher 
Table (12): ANOVA test for Total differences considering preparation program institution

\begin{tabular}{llllll}
\hline Total & Sum of Squares & $d f$ & Mean Square & $F$ & Sig. \\
\hline Between Groups & 14.087 & 6 & 2.348 & 5.272 & .000 \\
Within Groups & 59.676 & 134 & .445 & & \\
Total & 73.764 & 140 & & & \\
\hline
\end{tabular}

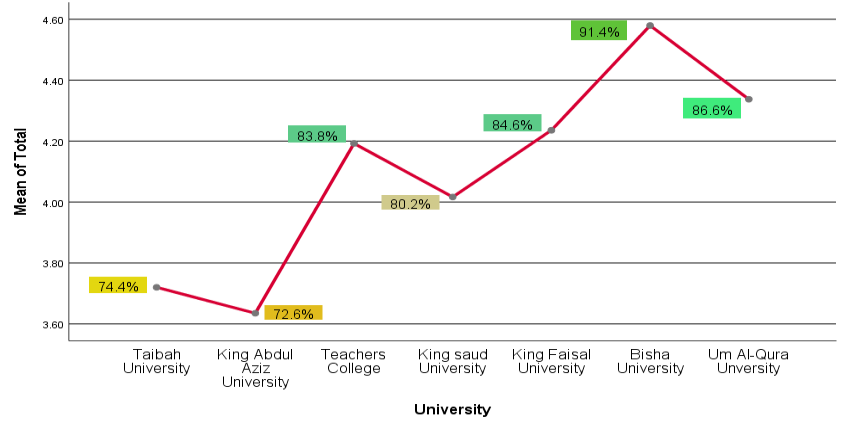

Figure 1: Percentage of TESOL standards in EFL teachers' preparation programs in Saudi Arabia

preparation program with the standards of TESOL (72.6\%), followed by Taibah University in Madinah (74.4\%). Although they were the lowest, they are in a good position concerning the standards of TESOL, and we suggest the shortcomings can be avoided in the future processes of developing their programs.

\section{Recommendations}

The findings of the study indicate a dire need for a serious review of the quality and content of the current EFL teacher training programs in Saudi Arabia. Professional training programs aim to develop well-rounded professionals with moderate to high skills in the implementation of all domains in the professional life. While it is true that some of these are fulfilled in the teacher prep programs in Saudi Arabia, there are other areas that need greater effort. In this background, the study recommends reviewing and updating the EFL teachers' preparation program at Saudi universities and Colleges of Education based on the TESOL standards to meet the students' needs, make changes to the EFL teachers' preparation programs to fit the graduates' capabilities, make a strategic plan to adopt TESOL standards and various models of EFL preparation programs at Saudi universities and colleges, invite the faculty members to attend TESOL conferences on EFL teachers' preparation programs.

\section{References}

Abu Allam, R. (2006). Research methods in psychological and educational sciences (5th ed.). Cairo: Universities publishing house.

Abu Hatab, F., \& Sadiq, A. (2010). Research approaches and methods of statistical analysis in the psychological, educational and social sciences. Cairo: The Anglo-Egyptian Library.
Abu Jeriban, T. (2020). The professional needs of Jordanian novice English language teachers from their own perspectives. IUG Journal of Educational and Psychological Sciences, 29(4), pp. 159 -175.

Al-Abiky, W. (2019). Bridging the gaps: EFL teacher preparation programs: A study in Saudi Arabian Context. Journal of Educational and Psychological Sciences, 3(32), pp. 184 - 168. https://doi.org/10.26389/AJSRP.W281019

Al-Ahdal, A. A. M. H., Alfallaj, F., Al-Awaied, S., \& Al-Hattami, A. A. (2014). A comparative study of proficiency in speaking and writing among EFL learners in Saudi Arabia. American International Journal of Contemporary Research, 4(2), 141-149.区

Alja'afreh, H. (2020). The effectiveness of new teachers course in developing the teaching competencies among the English teacher in directorate of education and teaching of the Karak Kasabh. Journal of Educational and Psychological Sciences, 4(23), pp. 19-37.

AlJebol, A. (2014). English Teachers' Perception Level in Different Educational Stages for their Professional Development in Public Schools in Ma'daba Governorate. Palestine: Middle East University .

AL-Muzeini, T., \& Al-Kahtani, H. (2020). A proposed conception for developing English language teacher preparation programs in the Kingdom of Saudi Arabia in light of the Ceap Standards. The Arab Foundation for Scientific Consultation and Human Resource Development, 69, pp. 14-49.

Alrwele, N. (2018). Assessment of English language student teachers' perceptions of their competency in light of teacher professional standards (ELTPSs) in the Kingdom of Saudi Arabia. The Arab Journal for Quality Assurance in Higher Education, 35(11),187218. https://doi.org/10.20428/AJQAHE.11.35.8

Alshuaifan, A. (2021). The role of EFL/ESL teacher preparation programs in raising the awareness of pre-sevice teachers of intercultural communicative competence model: A comparative study between Saudi Arabia and Singapore. International Journal of Education and Practice, 2(9),. 230-255. DOI:10.18488/journal.61.2021.92.230.255

AlShukri, H. (2018). Evaluation of the English language teacher preparation program at the college of education in Rustaq from the point of view of the students of the specialty. International Journal of Educational \&Psychological Studies, 4(1). 75-95.

Goff, P., Yang, H., Yang, M., Batt, L., Xie, X., \& You, E. (2020). A new evaluation approach for teacher preparation programs using labor market competitiveness of teacher applicantss (WCER Working Paper No. 2020-3). University of Wisconsin-Madison, Wisconsin Center for Education Research. Retrieved from https://wcer.wisc.edu/docs/working-papers/WCER Working Paper No 2020 3.pdf

Manaserah, M., \& Al-Halali, A. (2017). The degree of teacher preparation programs in achieving social development 
aims. Al-Quds University Open Journal for Educational and Psychological Research and Studies, 5(18), 179-194.

Meihami, H. (2021). EFL teachers' professional identity development through potentially exploitable pedagogical activities. International Journal of Language Studies, 15(2), 47-66.

Melham, S. (2000). Research methods in education and psychology. Amman: Dar Al-Masira for Publication and Distribution.

Shaldan, F., \& Abu Leilah, H. (2017). The status of the programs of preparing English language teachers in the light of Ncate standards at Palestinian universities, Ghaza. The Arab Journal of Quality Garantee of University Education(31), pp. 45-75. doi: https://doi.org/10.20428/AJQAHE.10.5.3
TESOL International Association (TESOL). (2019). Standards for Initial TESOL Pre-K-12 Teacher Preparation Programs. Alexandria: VA: Author. .

Ürün Göker, M. (2021). Reflective coaching: Training for development of instructional skills and sense of efficacy of pre-service EFL teachers. Journal of Language and Linguistic Studies, 17(Special Issue 1), 423-447

Youcef, M., \& Taoufik, D. (2015). Assessing professional quality in EFL pre-service training programme at the department of English at Tlemcen University. Arab World English Journal, Agust, pp. 127 - 147.

Youssef, F. (2020). Modern teacher and the challenges of the twentyfirst century. Journal of Educational and Psychological Sciences, 4(19), pp. 110-130. https://doi.org/10.26389/AJSRP.C211219 